\title{
SUBSTANSI ANTI BAKTERI DARI JAMUR ENDOFIT PADA MANGROVE Avicennia marina
}

\author{
(Substance Anti Bacteria from Endofit Fungi in Mangrove Avicennia marina)
}

\author{
Febrian A. Ramadan ${ }^{{ }^{\star}}$, Robert A. Bara ${ }^{1}$, Fitje Losung ${ }^{1}$, \\ Remy E.P. Mangindaan ${ }^{1}$, Veibe Warouw ${ }^{1}$, Silvester B. Pratasik ${ }^{2}$
}

1. Program Studi Ilmu Kelautan, Fakultas Perikanan dan IImu Kelautan, Universitas Sam Ratulangi, Manado.

2. Program Studi Manajemen Sumberdaya Perairan, Fakultas Perikanan dan IImu Kelautan, Universitas Sam Ratulangi, Manado.

*e-mail : febrianarthar@gmail.com

Mangrove is a type of plant that produce bioactive compounds. The bioactive compounds contained in the mangrove are not necessarily derived from the mangrove itself, but can be derived from from other microorganisms that synthesize bioactive compounds within mangroves. Thus there are the group of endophytic fungi or bacteria reside in mangrove that acting as a true bioactive producer. Six fungal endophyte were isolated from mangrove Avicennia marina growing at Tasik Ria Bay, Minahasa Regency. The Antibacterial test was conducted using modified Kirby-Bauer method. Two isolates, A.M.D 1.1.1 and A.M.D 1.1.2 show active against Bacillus megaterium and Escherichia coli. Further microscopic analysis on the basis of their mycelia appearance indicates these two isolates are Aspergillus cf. flavus and Talaromyces sp., respectively. The extract of these isolates were further fractioned, obtained 3 fractions of water, ethanol and $n$-hexane. All of these fractions were tested once more and show antibacterial activities as well. This research indicates that the antibacterial compounds produced by these isolates are ranging from polar, to nonpolar characteristics. Spectrophotometric analysis on the basis of UV absorption showed that the active compounds from both isolates are different.

Keywords: endophyte, Avicennia marina, antibiotics, Bacillus megaterium, Escherichia coli

Mangrove merupakan suatu tumbuhan yang kaya akan senyawa bioaktif. Senyawa bioaktif yang terdapat dalam bagian-bagian mangrove tidak selalu berasal dari tanaman mangrove itu sendiri, melainkan dari organisme lain yang mensintesis senyawa bioaktif di dalam bagian mangrove. Dengan demikian ada kemungkinan terdapat jamur atau bakteri endofit yang hidup atau tinggal di tumbuhan mangrove dan berperan sebagai penghasil bioaktif yang sebenarnya. Telah diisolasi enam isolat jamur endofit asal mangrove Avicennia marina yang tumbuh di Peariran Pantai tasik Ria, kabupaten Minahasa. Pengujian aktivitas antibakteri dalam penelitian ini menggunakan metode Kirby-Bauer yang dimodifikasi. Hasil yang diperoleh dalam penelitian ini terdapat isolat jamur endofit dari mangrove Avicennia marina. Hanya 2 isolat jamur endofit yaitu A.M.D. 1.1.1. dan 1.1.2. yang memiliki aktivitas antibakteri terhadap bakteri $B$. megaterium dan $E$. coli. Analisis mikroskopik dari kedua isolat berdasarkan bentuk miselium mengindikasikan kedua isolat ini yaitu Aspergillus cf. flavus dan Talaromyces sp. Ekstrak kedua isolat jamur kemudian fraksinasi dan diperoleh 3 fraksi yaitu fraksi air, etanol dan $n$-heksan. Dari ketiga fraksi semuanya memiliki aktivitas antibakteri. Hal ini menunjukkan bahwa senyawa dari isolat jamur endofit bersifat polar,semi polar dan non polar. Hasil spektrofotometri menunjukkan bahwa senyawa antibakteri dari isolat jamur strain Aspergillus cf. flavus dan Talaromyces spmerupakan senyawa yang berbeda. Fraksi aktif dari strain Aspergillus cf. flavus dan Talaromyces spterdapat pada fraksi n-heksan, etanol dan air. Ketiga fraksi ini memiliki perbedaan pola serapan UV.

Kata kunci: endofit, Avicennia marina, antibiotik, Bacillus megaterium, Escherichia coli 


\section{PENDAHULUAN}

Indonesia merupakan negara tropis yang kaya dengan flora dan fauna sehingga banyak jenis tumbuhan hewan menjadi sumber plasma nuftah yang tidak ternilai. Beberapa tahun terakhir penggalian sumber daya mikrobia yang terdapat di dalam jaringan tanaman mulai banyak mendapat perhatian (Melliawati, 2006). Mikroba yang terdapat dalam jaringan tanaman dikelompokkan sebagai mikroorganisme endofit. Senyawa dari jamur endofit bisa dikembangkan menjadi bahan obat. Jamur endofit yang berasal dari tumbuhan telah diaplikasikan untuk keperluan industri juga medis dan pertanian (Clay, 1988).

Wightman (1989) mendefinisikan mangrove sebagai komunitas tumbuhan yang terdapat di daerah pasang surut. Mangrove juga didefinisikan sebagai formasi tumbuhan daerah litoral yang khas di pantai daerah tropis dan sub tropis yang terlindung (Saenger et al., 1983). Beberapa ilmuwan menyatakan, bioaktivitas yang terdapat dalam bagianbagian tumbuhan mangrove tidak selalu berasal dari tumbuhan mangrove itu sendiri, namun dapat berasal dari organisme lain yang hidup di bagian dari tumbuhan mangrove dan organisme ini bisa mensintesis senyawa bioaktif yang bersifat sebagai antibakteri (Phoanda, 2014; Maria, 2005; Liebezeit et al., 2006; Rajendran, 2006; Huang et al., 2007; Liwang, 2014).

Secara etimologi endofit dapat diartikan "organisme yang tinggal dan hidup dalam tumbuhan" (dari bahasa Yunani; Endo = dalam, phyton =tumbuhan) (Kobayashi dan Palumbo, 2000). Mikroba endofit dapat ditemukan hampir di semua tumbuhan dan merupakan organisme hidup berukuran mikroskopis yang hidup di dalam jaringan tanaman selama periode tertentu dari siklus hidupnya (Tarigan dan Kuswandi, 2010), yang dapat dijumpai pada bagian akar, daun serta batang tumbuhan. Mikroba endofit memiliki keanekaragaman yang luas. Hampir 300.000 spesies tanaman yang ada di bumi, masing- masing individu tumbuhan memiliki satu atau lebih jenis mikroba endofit (Strobel dan Daisy, 2003).

Liwang et al. (2014) berhasil mengisolasi 2 spesies jamur endofit dari daun mangrove $A$. marina telah di isolasi 2 spesies jamur endofit dengan karakteristik miselia yang berbeda.

Melalui metode ko-kultvasi, kedua isolat kemudian diuji cobakan untuk tumbuh bersama dengan bakteri patogen E. coli dan S. aureus untuk melihat daya hambat kedua isolat terhadap pertumbuhan bakteri tersebut di atas. Beberapa laporan penelitian tentang jamur endofit asal organisme laut asal Sulawesi Utara tidak hanya menunjukkan bioaktivitas yang kuat tetapi juga diversitas senyawa yang beragam (Kartika et al., 2014; Liwang et al., 2014; Phoanda et al., 2014; Sumampouw et al., 2014; Dwilestari et al., 2015; Faraknimella et al., 2015; Kasi et al., 2015; Menggelea et al., 2015; Santoso et al., 2015; Nawea et al., 2016; Prasetyo et al., 2017). Dengan demikian perlu dilakukan penelitian mengenai tumbuhan laut khususnya mangrove dalam upaya penemuan senyawa antibakteri. Tujuan dari skripsi ini mengisolasi jamur yang terdapat pada akar, batang dan daun mangrove A.marina yang tumbuh di sekitar Pantai Tasik Ria, menentukan antimikroba dari jamur yang diisolasi dari mangrove $A$. marina terhadap bakteri uji B. megaterium dan E. coli dan Membandingkan aktivitas antimikroba setiap fraksi dari ekstrak isolat jamur endofit pada daun yang aktif

\section{METODE PENELITIAN}

\section{Lokasi Pengambilan Sampel}

Pengambilan sampel dilakukan di Pantai Tasik Ria (Gambar 1), selanjutnya isolasi jamur dan ekstraksi dilakukan di Laboratorium Biologi Molekuler dan Farmasetika Fakultas Perikanan dan IImu Kelautan Universitas Sam Ratulangi Manado. 


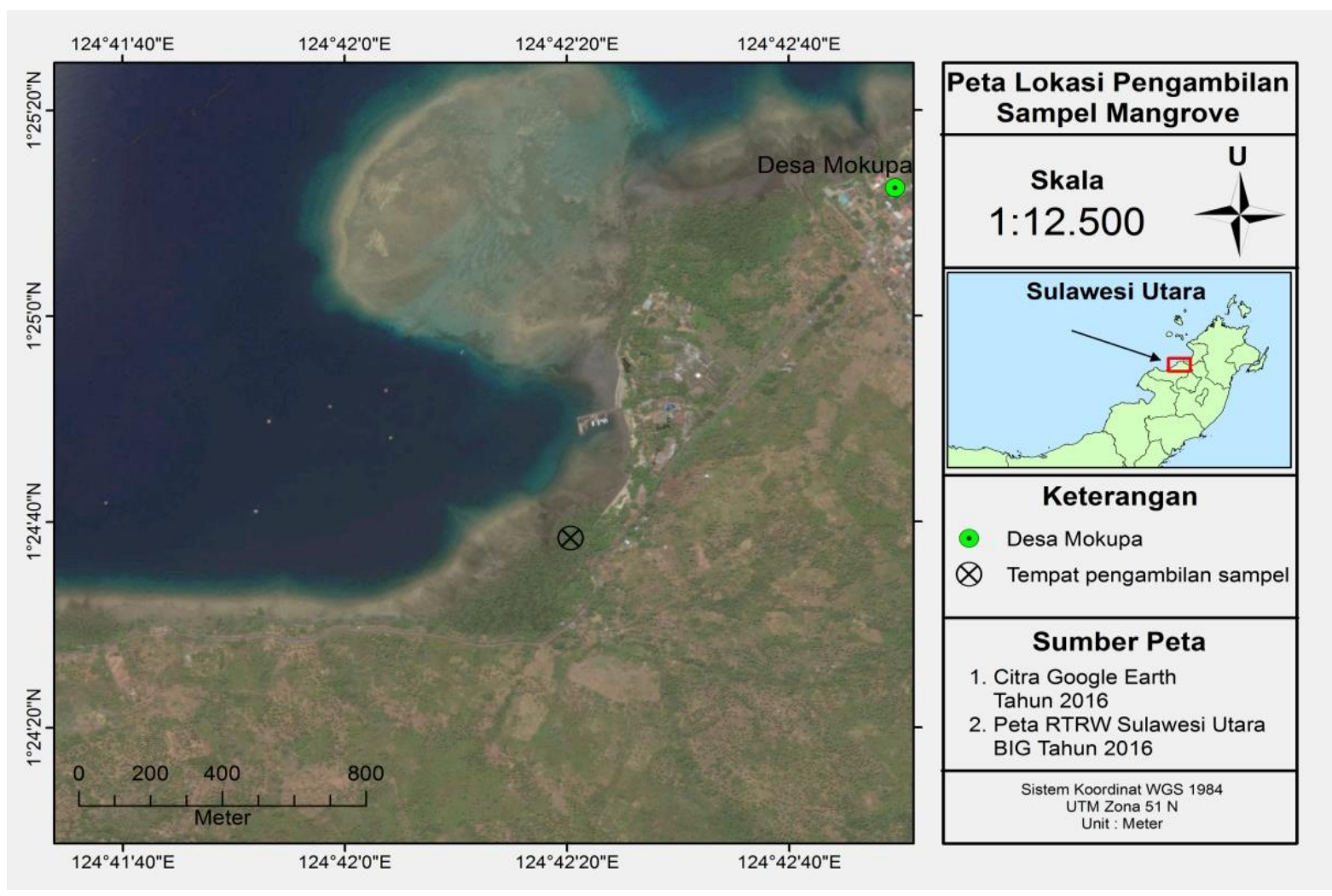

Gambar 1. Peta Pengambilan Sampel

\section{Sterilisasi Alat dan Media}

Alat-alat yang digunakan dalam penelitian ini seperti cawan petri, tabung reaksi, scalpel, gunting dan pinset dicuci bersih, dikeringkan, dibungkus kemudian disterilkan dalam oven pada suhu $150^{\circ} \mathrm{C}$ selama \pm 2 jam (sterilisasi kering). Media untuk pertumbuhan mikroorganisme disterilisasi dalam autoklaf pada suhu $121^{\circ} \mathrm{C}$ selama 15 menit (sterilisasi basah).

\section{Pembuatan Media}

\section{Yeast Extract Agar}

Proses pembuatan media isolasi jamur (YSA) yaitu, Yeast extract : 0,1 gram, Soluble Starch : 0,5 gram dan Agar : 1,5 gram. Bahan-bahan yang telah ditimbang dimasukkan ke dalam erlenmeyer lalu ditambahkan $100 \mathrm{ml}$ air laut 50\%. Selanjutnya disterilisasi menggunakan autoklaf dengan suhu $121^{\circ}$ C selama 15 menit, kedalam media ditambahkan kloramfenikol

\section{Potato Dextrose Agar}

Potato Dextrose Agar (PDA) dibuat dengan cara sebagai berikut: kentang direbus dengan air laut $50 \%$ hingga lunak selanjutnya disaring. Filtrat yang di peroleh ditambahkan agar dan dextrose kemudian disterilkan dalam autoklaf pada suhu $121^{\circ} \mathrm{C}$ selama 15 menit. Selanjutnya media dituang ke dalam petridis yang steril setelah itu media didinginkan dan siap digunakan.

\section{Media Nasi}

Beras sebanyak 50 gram dimasukkan ke dalam erlenmeyer lalu ditambahkan air laut $50 \%$ sebanyak $100 \mathrm{ml}$. Setelah itu disterilisasi dalam autoklaf selama 15 menit pada suhu $121{ }^{\circ} \mathrm{C}$, selanjutnya media nasi siap digunakan.

\section{Media Nutrient Agar (NA)}

Untuk pembuatan NA semua bahan ditimbang , seperti agar 1,5 gram, NB 1,0 gram dan dilarutkan dalam $100 \mathrm{ml}$ air laut $50 \%$ dimasukkan ke dalam erlenmeyer lalu diaduk menggunakan magnetik stirrer. Setelah bahan larut, erlenmeyer ditutup 
dengan kapas dan dilapisi aluminium foil kemudian disterilisasi dengan menggunakan autoklaf selama \pm 15 menit dengan suhu $121^{\circ} \mathrm{C}$. Media NA yang telah steril kemudian dituang secara aseptik ke dalam cawan petri steril secara merata, selanjutnya media didiamkan hingga mengeras.

\section{Isolasi Jamur}

Daun, batang dan akar tumbuhan mangrove jenis $A$. marina diambil dari Pantai Tasik Ria. Selanjutnya dipotong kira-kira $5 \mathrm{~cm}$ dan direndam selama 2 jam dalam $50 \%$ air laut yang mengandung kloramfenikol untuk menghindari kontaminasi silang mikroba epifit. Selanjutnya dipindahkan ke larutan berikutnya dan direndam selama 2 jam. Potongan tersebut selanjutnya dipindahkan ke media Yeast Extract Agar yang telah disiapkan. kemudian simpan pada suhu ruangan untuk menumbuhkan jamur. Setelah kurang lebih 2-3 hari akan terlihat pertumbuhan dari jamur disekitar sampel yang telah diletakkan di media agar. Miselia jamur yang telah tumbuh pada media kemudian secara bertahap dimurnikan satu-persatu dengan menggunakan kawat ose steril dan dipindahkan ke media steril pada cawan petri lainnya, dan diinkubasi pada suhu ruangan.

\section{Skrining Aktivitas Antibiotik dari Jamur Endofit}

Media Nutrien Agar diolesi bakteri uji (B. megaterium DSM $32^{\top}$ dan E. coli DSM 498). Jamur-jamur endofit yang sudah tumbuh diambil dengan menggunakan sedotan steril dan diletakkan di atas media lalu diinkubasi pada suhu ruangan selama 1-2 x 24 jam. Setelah itu, jamur edofit tersebut diamati aktivitas antibiotiknya terhadap bakteri (B. megaterium DSM $32^{\top}$ dan E. coli DSM 498). Selanjutnya jamur-jamur endofit yang memiliki aktivitas antibiotik dikultivasi pada media nasi yang telah disiapkan.

\section{Kultivasi dan Ekstraksi Jamur pada Media Nasi}

Jamur endofit yang memiliki aktivitas antibiotik dikultivasi pada media nasi dan selanjutnya diinkubasi selama 2 minggu pada suhu ruangan. Proses ekstraksi dilakukan setelah pertumbuhan miselia jamur endofit sudah mencapai bagian dasar dari labu erlenmeyer. Proses ini dilakukan dengan cara maserasi dinamis menggunakan pelarut etil asetat selama 24 jam. Selanjutnya difiltrasi untuk mendapatkan filtrat-filtrat jamur dan diuapkan menggunakan Rotary vacuum evaporator pada suhu $40^{\circ} \mathrm{C}$ sehingga didapatkan ekstrak kasar jamur.

\section{Uji Aktivitas Antibakteri dari Ekstrak Jamur}

Nutrien agar ditambahkan bakteri uji yang telah ditumbuhkan pada media NB selama 24 jam. Setelah itu dikocok perlahan dan dituang ke dalam petri steril kira-kira $20 \mathrm{ml} /$ petri setelah padat diletakkan kertas cakram yang sudah ada ekstrak uji $50 \mu$ lalu diinkubasi selama 24 jam pada suhu ruangan. Kemudian, diamati aktivitas antibakteri dari ekstrak jamur terhadap (B. megaterium DSM $32^{\top}$ dan E. coli DSM 498). Apabila sampel uji menghambat pertumbuhan bakteri, maka akan terlihat daerah bening di sekitar sumur. Kemudian diukur diameter zona hambat $(\mathrm{mm})$ yang terbentuk dengan menngunakan penggaris. Ekstrak kasar yang menunjukan aktivitas antibiotik akan dipartisi.

\section{Partisi} aktivitas antibiotik terbesar dipartisi dengan pelarut heksan dan metanol. Prosedur kerja partisi (Gambar 9) dilakukan dengan menambahkan heksan dan methanol. Kemudian larutan dimasukan ke dalam corong pisah (separotory funnel) lalu dikocok dan didiamkan selama 10 menit, sehingga akan terlihat 2 lapisan yaitu lapisan heksan dan metanol. Lapisan heksan dan metanol di tampung pada wadah yang berbeda dan diuapkan dengan menggunakan rotary vaccum evaporator sehingga diperoleh fraksi heksan dan metanol. Selanjutnya hasil fraksinasi diuji kembali aktivitasnya untuk mengetahui lokasi senyawa aktif yang berada. 


\section{Spektrofotometri UV-Vis}

Semua fraksi yang aktif akan dilihat senyawa antibakteri menggunakan spektrofotometri UV-Vis. Hal ini bertujuan untuk mengukur absorbansi dengan cara melewatkan cahaya dengan panjang gelombang tertentu.

\section{HASIL DAN PEMBAHASAN}

Hasil pembiakan yang diisolasi dari daun, batang dan akar mangrove $A$. marina yang diambil dari pantai Tasik Ria pada media agar terdapat 6 jamur yang dari A. marina. Pada bagian akar didapatkan 2 isolat jamur endofit, di bagian batang didapatkan 2 isolat jamur endofit dan pada bagian daun didapatkan 2 isolat jamur yang tumbuh. Pada bagian tanaman yang berbeda dapat diisolasi jamur endofit yang bervariasi/berbedabeda bentuk koloni dan perbedaan warna pada miselia. Isolat jamur yang tumbuh pada bagian akar memiliki karakteristik miselia berwarna kuning dan hijau berserbuk, di bagian batang isolat jamur memiliki miselia dengan karakteristik warna hijau tua dan pada bagian daun berwarna putih kehijauan berserbuk dan putih kekuningan berserabut.
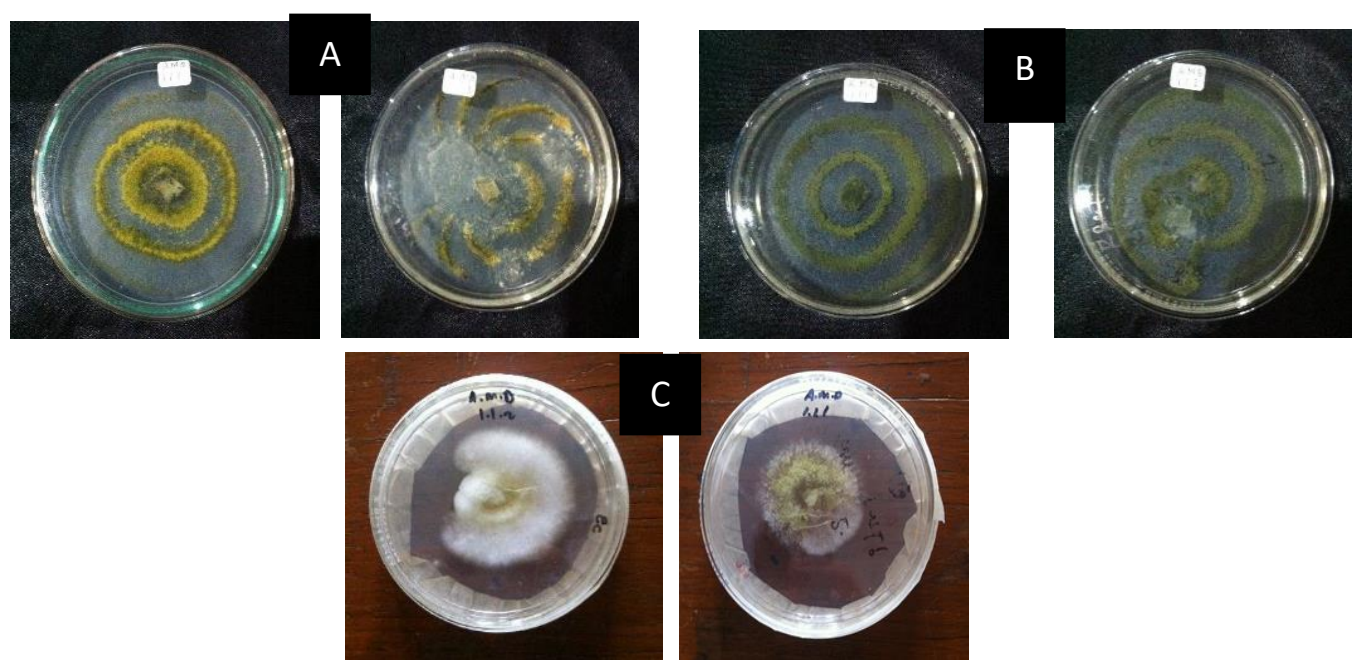

Gambar 2.Morfologi koloni isolat jamur endofit dari akar (A), batang (B) dan daun (C) mangrove A. marina

Tabel 1. Uji aktibakteri endofit mangrove $A$. marina terhadap bakteri $S$. aureus dan $E$. coli

\begin{tabular}{cccc}
\hline \multicolumn{2}{c}{ Kode isolat } & S.aureus & E. coli \\
\hline $\begin{array}{c}\text { Isolat Akar } \\
1 .\end{array}$ & A.M.A 1.1.1 & - & - \\
2. & A.M.A 1.2.1 & - & - \\
Isolat Batang & & & - \\
1. & A.M.B 1.1.1 & - & - \\
2. & A.M.B 1.1.2 & - & - \\
Isolat Daun & A.M.D 1.1.1 & + & - \\
1. & A.M.D 1.1.2 & + & \\
2. & & &
\end{tabular}

Keterangan: (-) tidak ada aktivitas dan (+) ada aktivitas 


\section{Hasil pengujian awal isolat jamur pada bakteri $S$. aureus dan $E$. coli}

Hasil pengujian dari 6 isolat jamur endofit terhadap bakteri $S$. aureus, menunjukkan adanya zona hambat pada isolat A.M.D 1.1.1 dan 1.1.2 dari jamur asal daun dari mangrove $A$. marina sedangkan untuk bakteri $E$. coli tidak menunjukkan adanya zona hambat dan untuk isolat jamur asal batang dan akar tidak memperlihatkan adanya daya hambat terhadap kedua bakteri uji. Hal ini menunjukkan jamur endofit yang diisolasi dari daun hanya mampu menghasilkan senyawa-senyawa aktif antibakteri pada S. aureus. Hasil pengamatan tersaji pada Tabel. 1

\section{Hasil Pengamatan Miselia Jamur Endofit Dari Daun Secara Mikroskopik}

Isolat jamur A.M.D. 1.1.1 dan 1.1.2 yang memiliki aktivitas antibakteri diteliti lebih lanjut secara mikroskopik memperlihatkan hifa berseptat dan miselium bercabang, sedangkan hifa yang muncul di atas permukaan merupakan hifa fertil, koloninya berkelompok, konidiofora bersepta atau nonsepta yang muncul sebuah gelembung, keluar dari gelembung ini muncul sterigma, pada sterigma muncul konidium-konidium yang tersusun berurutan mirip bentuk untaian mutiara, konidium-konidium ini berwarna (kuning tua sampai kehijauan) yang memberi warna tertentu pada jamur. Berdasarkan ciri-ciri tersebut di atas isolat A.M.D 1.1.1 (Gambar 3(A) diidentifikasi sebagai Aspergillus cf. flavus. (Schlegel, 1994).

Pada isolat lainnya (A.M.D 1.1.2) pengamatan mikroskopik memperlihatkan hifa bersepta dan membentuk badan spora yang disebut konidium. Konidium berbeda dengan sporangim, karena tidak memiliki selubung pelindung seperti sporangium. Tangkai konidium disebut konidiofor, dan spora yang dihasilkannya disebut konidia, seperti terlihat pada strain jamur Talaromyces sp. Beberapa jenis Talaromyces yang terkenal antara lain $\mathrm{T}$. wortmannii yang juga memproduksi senyawa antibiotik Flavomannin A dan B (Bara et al , 2013). Berdasarkan ciri-ciri di atas, isolat A.M.D 1.1.2 (Gambar 3 (B) diidentifikasi sebagai Talaromyces sp.

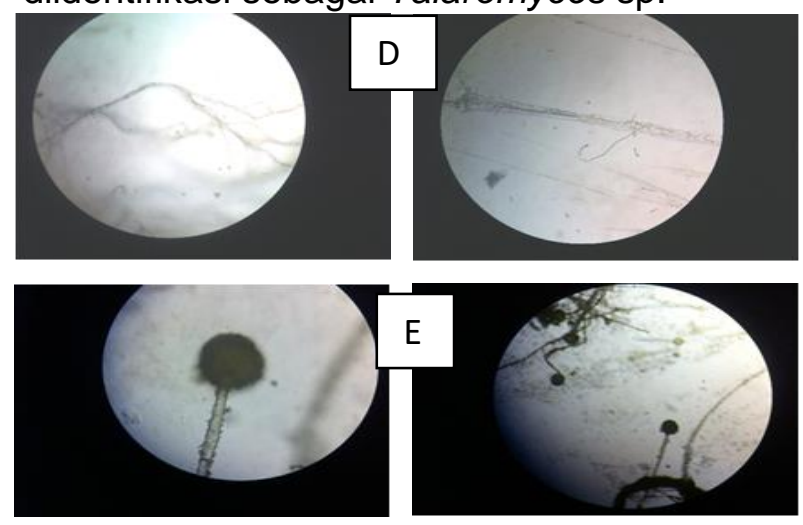

Gambar 3. D. A.M.D 1.1.1 (Aspergillus cf. flavus) dan E. A.M.D 1.1.2 (Talaromyces $\mathrm{sp})$

\section{Ekstraksi Jamur Endofit pada Media Nasi}

Strain Aspergillus cf. flavus dan Talaromyces sp. selanjutnya dikultur pada media nasi untuk mendapatkan biomassa ekstrak jamur yang lebih banyak untuk diteliti lebih lanjut. media nasi sebanyak 12 erlenmeyer kemudian diinkubasi statik pada suhu ruangan selama 14 hari.

Proses inkubasi dihentikan dengan cara maserasi dengan menambahkan etil asetat kedalam kultur selama 24 jam. Ekstrak kemudian disaring, filtrat yang diperoleh dievaporasi untuk menguapkan pelarut lalu setelah selesai dimasukkan ke dalam pengeringan beku untuk mendapatkan ektrak kering dari kedua jamur tersebut. Sebelum memasukkan ekstrak ke dalam pengeringan beku, ekstrak dibekukan terlebih dahulu di dalam kulkas agar proses pengeringan beku berjalan cepat. Kedua ekstrak tersebut kemudian diuji kembali aktivitas antibakterinya

\section{Partisi dan Uji Aktivitas Antibiotik}

Partisi dan uji aktivitas dilakukan untuk melihat fraksi mana pada ekstrak jamur yang memberikan aktivitas zona hambat pada bakteri uji $B$. megaterium dan E. coli. Dari tahapan fraksinasi ini didapatkan tiga hasil dari fraksinasi yaitu fraksi air, fraksi etanol dan fraksi nheksan, Senyawa-senyawa polar terlarut pada fraksi air, senyawa semi polar terlarut pada fraksi etanol sedangkan 
senyawa-senyawa yang sifatnya non polar terlarut pada fraksi n-heksan.

Ketiga fraksi yang telah didapatkan diuji aktivitas untuk melihat fraksi mana terkandung senyawa yang memiliki aktivitas terhadap bakteri uji $B$. megaterium dan E. coli pada media NA. Gambar 4 memperlihatkan adanya zona terang hampir di semua fraksi isolat jamur A.M.D 1.1.1 dan A.M.D 1.1.2 serta kontrol positifnya. Hasil pengukuran diameter zona hambat fraksi Strain Aspergillus cf. flavus dan Talaromyces sp spterhadap $B$. megaterium dan bakteri $E$. coli dapat dilihat pada Tabel 1. Hasil penelitian pada kedua ekstrak ini menunjukkan bahwa aktivitas antibakteri yang dilihat dengan adanya zona hambat, hanya ditemukan pada bakteri $B$. megaterium DSM 32T dan tidak terlihat adanya aktivitas antibakteri terhadap bakteri E. coli DSM 489. Hal ini menunjukkan bahwa senyawa dari Aspergillus cf. flavus dan Talaromyces sp. merupakan senyawa antibakteri yang lebih spesifik terhadap bakteri Gram positif.
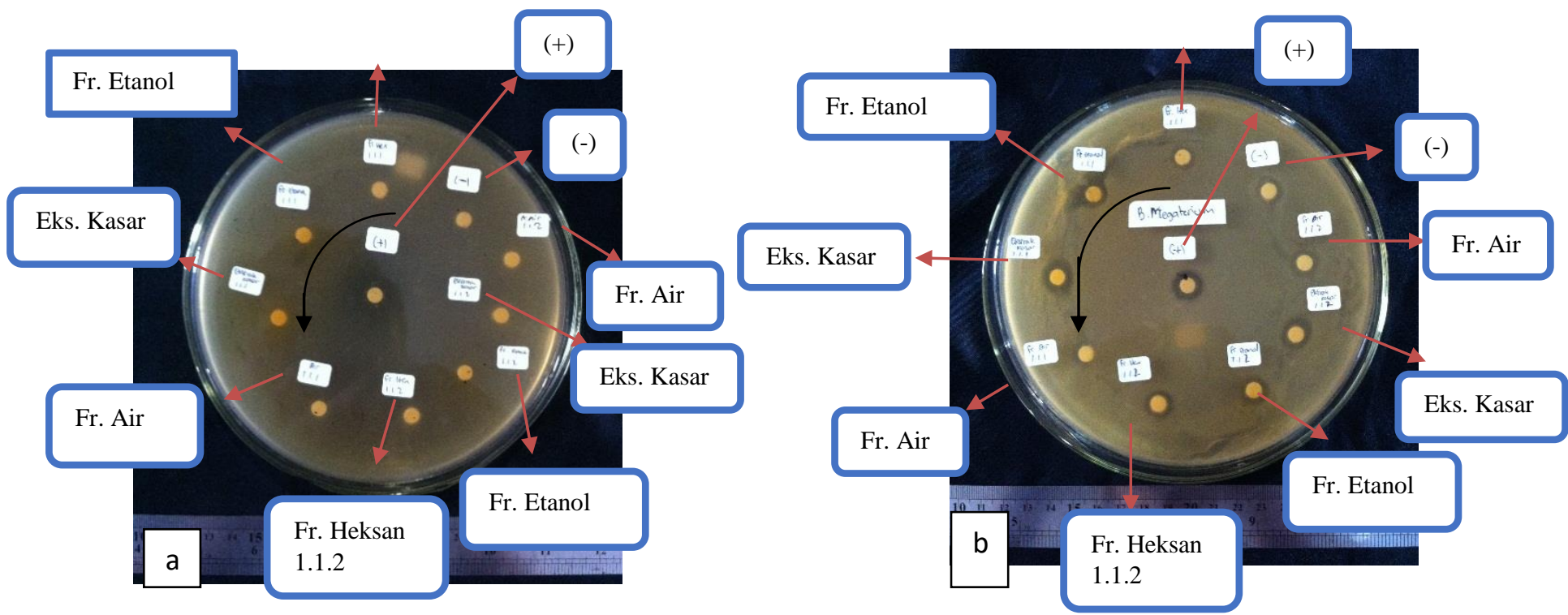

Gambar 4. Hasil pengujian aktivitas anti bakteri fraksi ekstrak Strain Aspergillus cf. Flavus dan Talaromyces sp. terhadap bakteri E. coli (a) dan B. megaterium (b)

Ket : Fr = Fraksi dan Eks = Ekstrak

Tabel 3. Daya Hambat Jamur pada Fraksi Ekstrak Jamur A.M.D 1.1.1 dan A.M.D 1.1.2

Terhadap Bakteri B. megaterium dan E. coli.

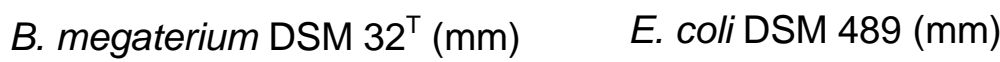

\begin{tabular}{lrrrrrrrr} 
& 1 & 2 & 3 & rata-rata & 1 & 2 & 3 & rata-rata \\
\hline & 11 & 9 & 8 & $9,3 \pm 1,5$ & - & - & - & - \\
\hline Fraksi n-heksana & 13 & 12 & 12 & $12,3 \pm 0,6$ & - & - & - & - \\
\hline Fraksi etanol & 12 & 11 & 13 & $12,0 \pm 1,0$ & - & - & - & - \\
\hline Fraksi air & 17 & 12 & 15 & $14,7 \pm 2,5$ & - & - & - & - \\
\hline Ekstrak kasar & & & & & & & & - \\
\hline \multicolumn{1}{r}{ Talaromyces sp } & 14 & 8 & 9 & $10,3 \pm 3,2$ & - & - & - & - \\
\hline Fraksi n-heksana & 12 & 9 & 10 & $10,3 \pm 1,5$ & - & - & - & - \\
\hline Fraksi etanol & 11 & 7 & 7 & $8,3 \pm 2,3$ & - & - & - & - \\
\hline Fraksi air & 18 & 11 & 9 & $12,3 \pm 4,7$ & - & - & - & - \\
\hline Ekstrak kasar & - & - & - & - & - & - & - & $27,3 \pm 0,5$ \\
\hline Kontrol $(-)$ & 13 & 13 & 14 & $13,3 \pm 0,6$ & 27 & 28 & 27 & \\
\hline Kontrol $(+)$ & & & & & & &
\end{tabular}




\section{Spektrofotometri UV-Vis}

Untuk membandingkan kandungan senyawa dari tiap fraksi dari kedua isolat jamur, penulis menggunakan pengamatan spektrum serapan UV-Vis yang kemudian membandingkan hasil serapan tiap fraksi tersebut satu dengan yang lain. Spektrum fraksi etanol Strain Aspergillus cf. flavus dan Talaromyces sp spdapat dilihat pada Gambar 5 dan 6.

Fraksi etanol Strain Aspergillus cf. flavus dan Talaromyces $\mathrm{sp}$ di atas merupakan senyawa yang sama. Persamaan ini dapat dilihat pada pola serapan UV yang terbentuk. Di mana Spektrum UV-Vis fraksi etanol Aspergillus cf. flavus menunjukkan empat serapan maksima pada panjang gelombang 230 , 270, 340 dan $440 \mathrm{~nm}$ (Gambar 5) hal serupa terlihat pada fraksi etanol Talaromyces sp dengan serapan UV maksima terlihat pada panjang gelombang 230, 270, 340 dan 480 nm (Gambar 6). Hal ini menunjukkan bahwa fraksi etanol Strain Aspergillus cf. flavus dan Talaromyces sp memiliki persamaan struktur senyawa utama. Fraksi n-heksan Aspergillus cf. flavus yang juga memperlihatkan adanya aktivitas antibakteri, menunjukkan lima serapan UV maksima yang berada pada panjang gelombang 220, 240, 265, 290 dan 360 $\mathrm{nm}$ (Gambar 7). Sedangkan pada fraksi nheksan Talaromyces sp menunjukkan juga lima serapan UV maksima pada 230, 270, 290, 340 dan 380 nm (Gambar 8). Namun, kedua fraksi ini memperlihatkan pola serapan UV yang berbeda, hal ini menunjukkan bahwa senyawa antibakteri dari fraksi n-heksan Strain Aspergillus cf. flavus dan Talaromyces sp kemungkinan merupakan senyawa yang berbeda. Perbedaaan dari kedua senyawa mungkin terletak pada gugus fungsi pada struktur utama.

Hal yang sama ditunjukksn pada fraksi air Strain Aspergillus cf. flavus dan Talaromyces sp seperti yang tersaji pada Gambar 24 dan 25. Kedua fraksi tersebut memperlihatkan sedikit perbedaan senyawa yang terlihat pada pola serapan UV yang terbentuk, di mana terdapat 3 serapan maksima dari fraksi air Aspergillus cf. flavus yang berada pada 265, 310 dan 360 nm (Gambar 9). Sedangkan, pada fraksi air Talaromyces sp hanya terdapat 2 serapan UV maksimum pada $255 \mathrm{~nm}$ dan $345 \mathrm{~nm}$ (Gambar 10). Hal ini menunjukkan bahwa senyawa antibakteri dari fraksi n-heksan Strain Aspergillus cf. flavus dan Talaromyces sp kemungkinan merupakan senyawa dengan struktur yang berbeda.

Dari perbandingan pola serapan setiap fraksi masing-masing isolat, baik Aspergillus cf. Flavus maupun Talaromyces $\mathrm{sp}$ memperlihatkan pola serapan UV yang berbeda satu dengan yang lainnya. Perbedaan pola serapan ini menunjukkan senyawa dari tiap fraksi ini merupakan senyawa yang berbeda.

Selanjutnya, serapan pada panjang gelombang kisaran 240 biasanya merupakan senyawa sikloheksana atau memiliki gugus aromatik pada struktur utamanya, sedangkan serapan pada kisaran panjang gelombang $400 \mathrm{~nm}$ biasanya merupakan senyawa dengan ikatan rangkap yang berselang-seling ( Manasa, 2014; Bara et al.,2013,a ; Walker et al., 1952; Tyukavkina et al., 1970; Bara et al., 2013,b; Teleb-Contini et al., 2003; dan Silverstein et al., 2005). 


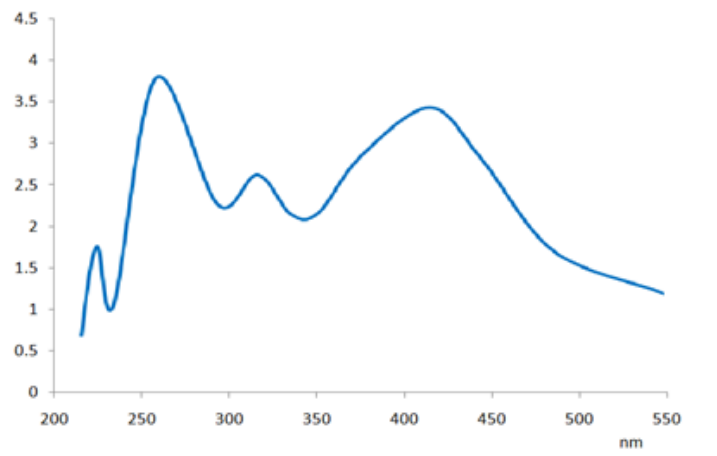

Gambar 5. Serapan UV fraksi etanol isolat jamur Aspergillus cf. flavus

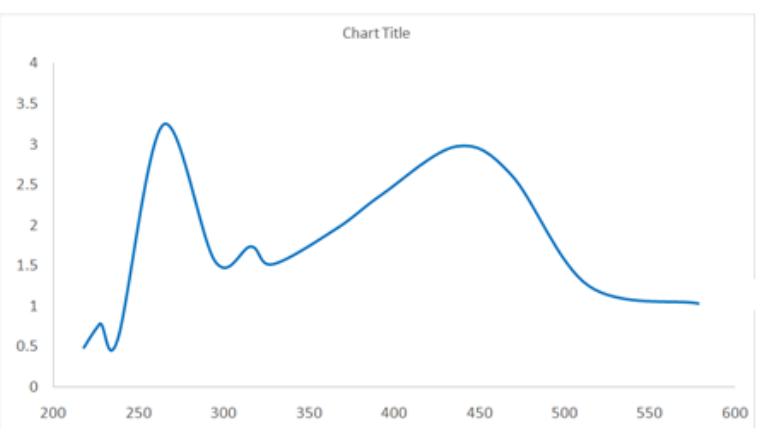

Gambar 6. Serapan UV fraksi etanol isolat jamur Talaromyces sp

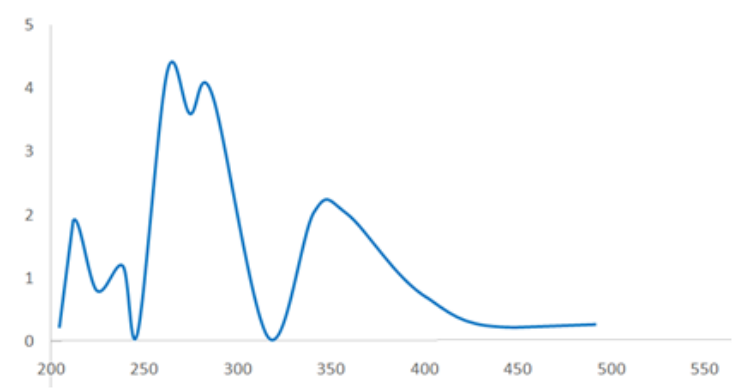

Gambar 7 . Serapan UV fraksi n-heksan isolat jamur Aspergillus cf. flavus

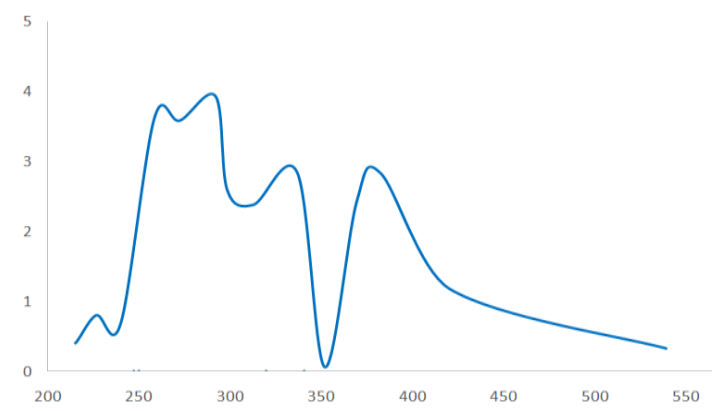

Gambar 8 . Serapan UV fraksi n-heksan isolat jamur Talaromyces sp 


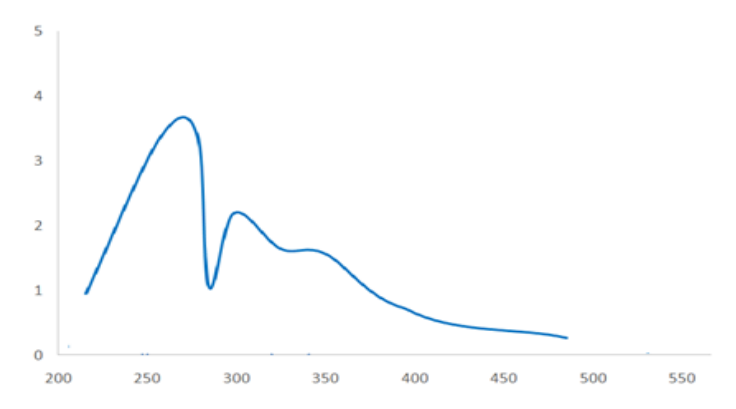

Gambar 9. Serapan UV fraksi air isolat jamur Aspergillus cf. flavus

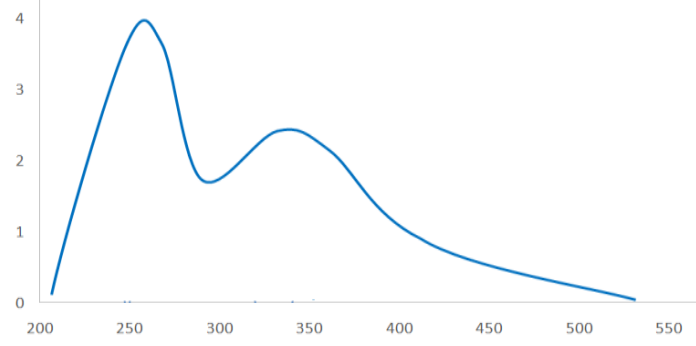

Gambar 10. Serapan UV fraksi air isolat jamur Talaromyces sp

\section{KESIMPULAN}

Berdasarkan penelitian yang dilakukan dapat disimpulkan bahwa Pertama ditemukan 6 isolat jamur simbion pada mangrove dan dari 6 isolat tersebut menunjukkan hanya dua isolat jamur endofit dari daun mangrove $A$. marina yang memiliki aktivitas terhadap bakteri senyawa antibakteri yang diperoleh hanya mampu menghambat pertumbuhan bakteri B. Megaterium, Kedua Fraksi aktif dari Strain Aspergillus cf. flavus dan Talaromyces $\mathrm{sp}$ terdapat pada fraksi nheksan, etanol dan air danKetiga fraksi ini memiliki perbedaan pola serapan UV.

\section{DAFTAR PUSTAKA}

Bara, R.A., Zerfaß, I., Lai, D. Lin, W. Debbab, A., Brötz-Oesterelt, $\mathrm{H}$. and 37 P. Proksch. 2013. New Natural Product from Botryosphaeria australis, an Endophyte from Mangrove Avicennia marina. Squalen Bulletin of Marine \& Fisheries, Postharvest \& Biotechnology. 8(3).139-145.
Bara, R., Amal, H., Wray, V., Lin, W., Proksch, P., Debbab. A. 2013. Talaromins A and B, New cyclic Peptides from The Endophytic Fungus Talaromyces worimannii. Tetrahedron Letters, 54:1686-9.

Clay, K. 1988. Fungal Endophytes of Grasses: A Defensive Mutualism Between Plants and Fungi. Ecology. 69(1):10-16.

Dwilestari, H. Awaloei, J. Posangi, R. Bara. 2015. Uji Efek Antibakteri Jamur Endofit pada Daun Mangrove Sonneratia alba terhadap Bakteri Uji Staphylococcus aureus dan Eschericia coli. Jurnal e-Biomedik Unsrat 3(1):394-398. .

Faraknimella, T. L., Bara, R., Wowor, P. M., Posangi, J. 2015. Uji Efek Antibakteri Jamur Endofit Akar Tumbuhan Bakau (Sonneratia alba) Terhadap Bakteri Staphylococcus aureus dan Escherichiae coli. Jurnal eBiomedik 3(3):785-88

Huang, H., She, Z., Lin, Y., Vrijmoed, L.L.P., Lin, W. 2007. Cyclic Peptides from an Endophytic 
Fungus Obtaid from a Mangrove Leaf (Kandelia candel). Journal of Natural Products. 70(11):16961699.

Kasi, Y. A., Posangi, J., Wowor, M. dan Bara, R. 2015. Uji Efek Antibakteri Jamur Endofit Daun Mangrove Avicennia marina Terhadap Bakteri Uji Staphylococcus aureus dan Shigella dysentriae. Jurnal eBiomedik 3(1):112-117.

Kartika, R., W. Bodhi, B. Kepel, R. Bara. 2014. Uji Daya Hambat Jamur Endofit Akar Bakau Rhizophora apiculata Terhadap Bakteri Staphylococcus aureus dan Escherichiae coli. Jurnal eBiomedik. 2(1):

Kobayasi, D.Y. dan J.D. Palumbo. 2000. Bacterial endophytes and thir effect on plants and uses in agriculture.in C. W. Bacon \& J. F. White, Jr (Eds). Microbial Endophytes (pp. 199-233). New York Marcel Dekker, Inc.

Liebezeit, G and. Rau M. 2006. New Guinean mangroves traditional usage and chemistry of natural products. Marine Biodiversity 36(1): pp 1-10.

Liwang, F., Bara, R., Awaloei, H., Wuisan. J. 2014. Uji aktivitas antibakteri jamur endofit akar bakau Avicennia marina terhadap bakteri Staphylococcus aureus dan Escherichia coli. E-journal Biomedik 2(1).

Manasa, G. 2014. Structural Elucidation of Terpenoids by Spectroscopic Techiniques. Jurnal of Chemical and Pharmaceutical Science. ISSN: 0974-2115.

Menggelea, F.P., Posangi, J., Wowor, P.M., Bara, R. 2015. Uji Efek Antibakteri Jamur Endosimbion Spons Laut Callyspongia sp. Terhadap Bakteri Pseudomonas aeruginosa dan Eschericia coli. Jurnal e-Biomedik, 3(1):376-380
Melliawati, R., Sukiman, H.I., Widyaningrum, D.N., Octavina, F., Sukmawati, E., and Simanjuntak, P. 2004. Studies on Indonesian endophytic microorganism and their potentials for plant protection of pathogen bacteria. Indonesian Biotechnology Conference. Konsorsium Bioteknologi Indonesia, Sanur, Bali, December 1-3rd

Maria, G.L., Sridhar, K.R. and Raviraja, N.S. 2005. Antimicrobial and enzyme activity of mangrove endophytic fungi of southwest coast of India. Journal of Agricultural Technology.

Nawea, Y., Bara, R.A. and Posangi, J. 2016. Antibiotic Analysis of Endophytic Fungi from Sonneratia alba Mangrove Growing in North Sulawesi Coastal Waters. Prosiding 1st International Seminar on Tropical Aquatic Resources Science \& Management, Manado (Poster).

Phoanda, T., Bara, R., Wowor, P. M. dan Posangi, J. 2014. Uji Efek Antibakteri Jamur Endofit Akar Tumbuhan Bakau (Bruguiera gymnorrhiza) Terhadap Bakteri Escherichia coli dan Staphylococcus aureus. Jurnal eBiomedik 2(1):1-5.

Prasetyo, G., R. Mangindaan, R. Bara. 2017. Antibacterial activity of endophytic fungi derived from sea grasses Enhalus acoroides and Thalassia hemprichii growing in Tongkaina Coastal Waters. Bachelor thesis.

Rajendran, N. dan Kathiresan, K. 2006. "Microbial flora associated with submerged mangrove leaf litter in India." International Journal Tropical Biology 55(2):393-400

Saenger, P., Hegerl, E.J. and Davie, J.D.S. 1983. Global status of mangrove ecosystems. The Environmentalist 3: 1-88. Also 
cited as: IUCN. Global Status of Mangrove Ecosystems. Gland: International Union for the Conservation of Nature and Natural Resources.

Santoso, V.P., J. Posangi, H. Awaloei, R. Bara. 2015. Uji Efek Antibakteri Daun Mangrove Rhizophora apiculata Terhadap Bakteri Pseudomonas Aeruginosa dan Staphylococcus aureus. Jurnal eBiomedik, 3(1):399-405.

Strobel, G., B. Daisy, U. Castillo, J. Harper. 2004. Natural Products from Endophytic Microorganisms. Journal of Natural Products 67(2):257-268.

Sumampouw M., Bara R., Awaloei H., Posangi J. (2013) Uji efek antibakteri jamur endofit akar bakau Rhizophora stylosa terhadap bakteri Staphylococcus aureus dan Escherichia coli. Jurnal E-Biomedik 2:1-5.

Tarigan, R. dan Kuswandi. 2010. Efektivitas Asal Isolat Bakteri Endofit dan Kerapatan Pengenceran dalam Mengendalikan Penyakit Busuk Batang (Sclerotium rolfsii Sacc) pada Tanaman Kedelai. Balai Penelitian Tanaman Buah Tropika Solok.

Teleb-Contini S. H., Salvador. M. J., Watanbe, E., Ito, I. Y., Oveira, D. C. R. D. 2003. Antimicrobial Actyvity of Flavonoids and Steroids Isolated from Two Chromolaena Species. Brazilian Journal of Pharmaceutical sciences 39 (4).

Tyukavkina, N.A., Pogodaeva N.N. and Lutski V. I. 1970. Ultraviolet absorption of Flavonoids.
Irkutstak Institute of Organic Chemistry, Siberian Division. Khimia Prirodynkh Soedinenli, Vol. 6(1):24-27.

Wightman, G. 1989. Mangroves of the Northern Territory. Northern Territory, Northern Territory Botanical Bulletin No.7. Conservation Commission of the Nortern Territory. Palmerston, N.T., Australia. 